\title{
Herod’s Western Palace in Jerusalem: Some New Insights
}

\author{
Orit Peleg-Barkat
}

The Hebrew University of Jerusalem

\begin{abstract}
Despite Josephus' detailed description of Herod's palace built on the Southwestern Hill of Jerusalem in Bellum Judaicum, book 5, only scant archaeological remains from its substructure were revealed so far, and only few scholars have attempted reconstructing its plan and decoration. A group of monumental Ionic columns, alongside a sculpted head of a lion, found in the Southwestern Hill in the vicinity of the supposed location of the palace, seems to have originated from the palace complex, attesting to its grandeur and unique character. Combining this evidence with Josephus' description and our vast knowledge of Herod's palatial architecture, based on excavated palace remains in other sites, such as Jericho, Herodium, Masada, Caesarea Maritima and Machaerus, allows us to present a clearer picture of the main palace of this great builder.
\end{abstract}

Keywords: Jerusalem, Second Temple Period, King Herod, Flavius Josephus, Architectural Decoration, Roman Architecture, Royal Ideology.

\section{Introduction}

Amongst the client kings ${ }^{1}$ of the early Roman Empire, Herod, King of Judaea (37-4 $\mathrm{BCE}$ ), is unmistakably the best known to scholarship, thanks to the detailed historical testimony of Josephus ${ }^{2}$ and the rich and well-preserved archaeological remains from his immense building program. These remains belong to a large array of sites and structures that he built within his kingdom, as well as beyond its boundaries, including entire cities, palace complexes, fortifications and fortresses, temples and temeni, theatres and hippodromes, bathhouses, mausolea, harbours, paved streets, and more. ${ }^{3}$ Most dominant

1 The term "client-king" is used here for reasons of convenience. For discussion concerning the term and contemporary examples, see: Braund 1984; Sullivan 1990; Paltiel 1991; Jacobson 2001; Roller 2003; Crighton 2009; Kaizer - Facella 2010; Kropp 2013.

2 Bellum Judaicum (=BJ) I; Antiquitates Judaicae (= AJ) XIV-XVII. On the image of Herod in Josephus' text, see for example: Landau 2006; Kasher - Witztum 2007; Schwartz 2013; Vermes 2014.

3 For a thorough survey and discussion of Herod's construction projects: Netzer 2006. For an updated survey of Herod's palaces: Netzer 2018. For further discussions on Herod's building program and the ideology it reflects, see: Roller 1998; Lichtenberger 1999; Japp 2000; Richardson - Fisher 2018. 
among his construction projects were the numerous palaces he established throughout the country. However, while the palaces he constructed in Caesarea Maritima, Herodium, Jericho, Cypros, Machaerus, and Masada are well known from the archaeological record, ${ }^{4}$ his main palaces in the capital city of Jerusalem remain a mystery. Only poor remains survive that could be assigned with certainty to these palaces. Any reconstruction, therefore, relies primarily on Josephus' description.

This article reexamines the detailed description of Herod's palace in Jerusalem by Josephus in his Bellum Judaicum, book 5, in light of the vast knowledge concerning Herodian palatial architecture gained through the excavations in his other palaces. It also assigns a group of monumental Ionic columns, alongside a sculpted head of a lion, found during Avigad's excavations on the Southwestern Hill (1969-1982) to Herod's palace, attesting to its grandeur and unique character and thus shedding light on this otherwise enigmatic structure.

\section{Herod's Western Palace in Jerusalem—General Background}

As much as we can infer from Josephus' text, Herod constructed two palaces in the city. The earlier is the Antonia Fortress, named for his earlier patron, Mark Antony, and therefore a pre-31 BCE date for its construction is certain (the year in which Octavian defeated Mark Anthony in the Battle of Actium). Built on the site of earlier Ptolemaic and Hasmonean strongholds (baris), the fortress was situated on the northwestern corner of the Temple Mount overlooking its vast compound. According to Josephus (BJ 5.238), the general appearance of this fortified-palace was that of a tower with other towers at each of its four corners, the southeastern tower higher than the rest. A similar arrangement of towers existed at Herod's Mountain Fortress-Palace in Herodium. ${ }^{5}$

To provide for his personal pleasure Herod build yet another, more luxurious palace, in the western part of the city, apparently around 25 BCE. $^{6}$ The fact that Herod built for himself more than one palace in the city is not surprising. Archaeological excavations have unearthed three Herodian palaces in Jericho, two at Masada and two at Herodium. Remains of Herod's palaces were also unearthed in Caesarea Maritima, Cypros, Machaerus, as well as, with some less clear archaeological evidence, at Hyrcania, Samaria/ Sebaste and Calirrhoe. Clearly, Herod was keen on luxury and royal splendor. In his palaces, we can discern a clear line of development in the architectural taste of the king; his later palaces are more complex and extend over a larger area than the earlier ones. They are located in dramatic spots, overlooking the view and their interior decoration is more elaborate and shows greater affinity with Roman fashions. ${ }^{7}$ Thus, for example, the Northern Palace in Masada spreads over three terraces along the northern cliff and the Third Palace of Herod in Jericho is divided between two wings on either side of Wadi

4 For final reports, see: Netzer 1981a (Herodium); Levine - Netzer 1986 (Caesarea); Netzer 1991 (Masada); Netzer 2001 (Jericho); Netzer - Damati 2004 (Cypros); Vörös 2013; Vörös 2015; Vörös 2019 (Machaerus).

5 Benoit 1975; Wightman 1990/1991; Netzer 2006, 120-126.

6 Netzer 2006, 129-132.

7 Foerster 1996; Rozenberg 2008, 333-367, 459-464; Peleg-Barkat 2014, 10. 
Qelt. Both palaces are richly decorated with wall decorations, mosaic floors or opus sectile floors and architectural decoration carved in stone and molded in stucco. ${ }^{8}$ This is in contrast to the earlier palaces at these sites - the Western palace at Masada and the First Palace at Jericho - that have an inverted plan and a simpler decoration.

Adequately, according to Josephus (BJ 5.176-182), the second palace of Herod in Jerusalem was a magnificent palace, which included a giant drinking hall, beautiful gardens with fountains and rooms for hundreds of guests. Namely, this palace had a much more luxurious character than the fortified palace in the eastern part of the city, whose main purposes were to supply protection for the king and preserve his control over the Temple Mount. ${ }^{9}$

As for the location of his western palace in Jerusalem, Josephus gives us the following information: "Adjoining and on the inner side of these towers, which lay to the north of it, was the king's palace" (BJ 5.177). The towers Josephus mentions are the three famous towers - Phasael, Hippicus and Mariamne — named after Herod's brother, friend and favorite wife, which Herod built along the western part of the northern line of the fortification of the city, in a strategic point, along the line of the transverse valley. One of these towers - alternatively recognized by scholars as either Hippicus or Phasael ${ }^{10}$ — has been traditionally identified with the massive tower still standing in the premises of the David Citadel ("Tower of David") near today's Jaffa Gate (in the Ottoman period wall of the Old City). Therefore, archaeologists have sought the remains of the palace to the south of this tower.

However, this search has yielded only scant remains that can be attributed to Herod's palace (see below). The main reason behind this paucity of finds lies in the destruction of the palace during the First Revolt, which Josephus describes in detail. At the start of the revolt, the Roman procurator Gessius Florus and his army camped inside the palace ( $B J$ 2.305) and used it to launch assaults on the citizens in order to release the soldiers besieged in the Antonia Fortress. In July $67 \mathrm{CE}$, after the Zealots captured the Upper City, Agrippa's soldiers and the moderate leadership escaped to the palace, but the Zealots put siege on the palace and on August 16 stormed it, killing the Roman soldiers, plundering the palace and setting it on fire (BJ 2.431-448). Nevertheless, we hear again of the palace toward the end of the revolt, after the Romans have already captured the Lower City and burnt the Temple, and the rebels, fortified themselves in the royal palace, which served as their last stronghold ( $B J$ 6.358). Titus, then, ordered embankments raised against the western wall of the palace in order to overcome the resistance and complete the conquest of the Upper City. The palace suffered further destruction during the fierce fighting. Only the three towers to its north remained untouched on Titus' orders (BJ 7.1).

Due to the destruction of the palace - first by the rebels, and then by the Roman soldiers - as well as the massive construction activity that took place in this strategic

8 For Masada's Northern Palace: Foerster 1995. For Herod's Third Palace in Jericho: Rozenberg 2008.

9 Netzer 2006, 129-132.

10 The measurements of the tower correspond better with the dimensions specified by Josephus for the tower of Phasael; however, the topographic location better suits the description of the tower of Hippicus in the junction between the "First Wall" and the "Third Wall." For the different opinions and the various arguments, see: Geva 1981; Bahat 1981; Tsafrir 2011, 60. 
location since its destruction and up until modern times, ${ }^{11}$ the architectural layout of the palace remains unknown, and only few scholars have attempted reconstructing its plan and decoration. Most elaborate of these attempts is Avi-Yonah's famous 1966 reconstruction of the palace created as part of the 'Holy Land Model,' depicting Jerusalem on the eve of the First Revolt (Fig. 1). ${ }^{12}$ Although Avi-Yonah designed his model before excavations took place in Herod's palaces in Jericho, Herodium, Cypros and Caesarea Maritima, and therefore could not rely on their finds, his model remains the predominant reference for scholars and nonprofessionals alike, when trying to visualize Herod's palace in Jerusalem.

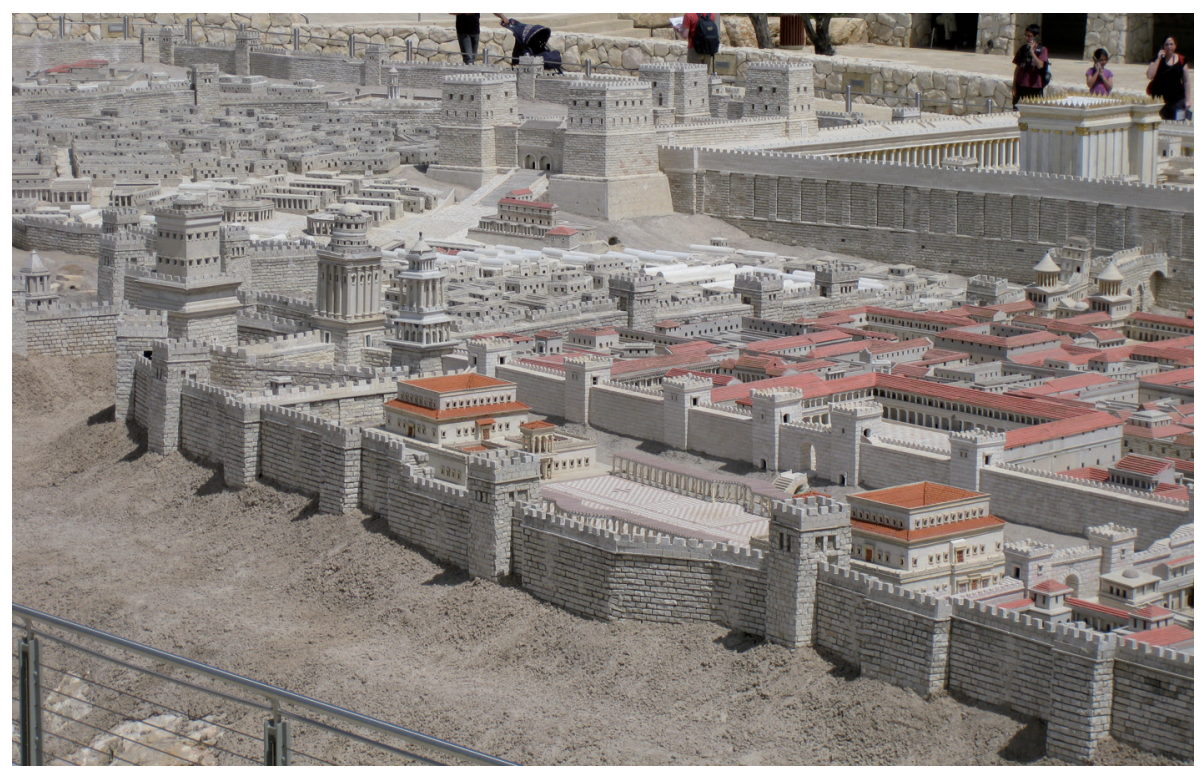

Fig. 1. Avi-Yonah's reconstruction of Herod's palace in Jerusalem (Judith McKenzie/Manar al-Athar)

The model shows a rectangular fortified palace aligned almost north-south along the western line of the Hasmonaean city wall ("First Wall"). The inner design is symmetrical. A large courtyard ${ }^{13}$ in the center of the palace is flanked by porticoes on the east and west - each with a semicircular exedra at its center - and by two identical wings to the north and south. The reconstruction of two identical wings arranged in a symmetrical design on both sides of a large court is based on a verse from the first book of Bellum Judaicum, where Josephus states that: “...(Herod's) own palace, which he erected in the upper city, comprised two most spacious and beautiful buildings, with which the

11 These activities include the foundation of the camp of the Tenth Roman Legion (if indeed it was established in this area), the construction of the palace of the Crusader Kings and the Ottoman Qishle: Re'em $2018,244$.

12 Avi-Yonah 1989; Tsafrir 2011, 59-60.

13 Originally, the courtyard had two round pools on each side of a grove; however, when the model was moved in 2006 to the Israel Museum, several adjustments were done and the courtyard with garden and pools was replaced by a paved court: Tsafrir 2011, 78-79. 
Temple itself bore no comparison. These he named after his friends, the one Caesareum, the other Agrippeum" (BJ 1.402). ${ }^{14}$ Although, the architectural plans of Herod's palaces in Jericho, Masada, Herodium and other sites, normally follow dominant architectural axes, absolute symmetry is always avoided, ${ }^{15}$ and emphasis is given to variety in shape and decoration of the various spaces. ${ }^{16}$ Considering this, we must envision Herod's palace in Jerusalem as a complex with a much more elaborate and diverse layout than is presented by Avi-Yonah's model. It must have included wings, rooms and courtyards of various shapes and designs. One of the wings or triclinia in the palace was named after Augustus, the other after Marcus Agrippa. ${ }^{17}$ The wings or halls were most probably different in design, just as these two historic figures were different in rank and character.

\section{Archaeological Remains of Herod's Palace ${ }^{18}$}

Unfortunately, the excavations inside the courtyard of David Citade ${ }^{19}$ and in the Qishle Compound (Ottoman prison) ${ }^{20}$ in the Old City of Jerusalem, as well as in the Armenian School $^{21}$ and Armenian Garden ${ }^{22}$ to their south have not yet revealed remains that can be

14 A similar statement appears in $A J 15.318$. While the word 'oốkovৎ' was translated by Thackeray (1927, 189 ) in his translation of $B J$ as 'buildings,' Marcus and Wikgren in their translation of $A J$ chose to translate it as 'rooms' $(1963,409)$. Netzer, accepting the latter translation, suggested that the huge triclinium B70 in Herod's Third Palace in Jericho fits well with Josephus' description of Herod's palace in Jerusalem and suggested reconstructing the triclinia, named after Augustus and Agrippa in the Jerusalem palace in a similar manner: Netzer 2006, 131.

15 See for example Netzer's discussion on the use of axes and symmetry in the design of the Herodium palace: Netzer 2006, 199-201.

16 The preference for variety of shapes in the design of Herod's palaces is seen for example in the utterly different architectural design of each of the terraces in the Northern Palace in Masada or the different layout of the northern and southern wings of Herod's Third Palace in Jericho.

17 Naming of cities, buildings or parts of buildings after the emperor or other members of the Imperial family was one of the means that Herod used in order to manifest his close connection with Augustus and Rome. E.g., the Antonia citadel named after Marc Antony, Caesarea (and its harbor Sebastos) and Sebaste named after Augustus, Livias after Livia, Agrippias after Marcus Agrippa, a lighthouse at the Caesarea's harbor was named after Drusus, and so forth: Lichtenberger 2009, 45-47.

18 For an updated and thorough description and analysis of the remains, see: Re'em 2018, 239-248.

19 Several expeditions excavated in David Citadel in the 20th century, led by British and later by Israeli archaeologists: Johns (1934-1974), Amiran and Eitan (1968-1969), Geva (1979-1980), and Solar and Sivan (1980-1988). Unfortunately, only the first excavations by Johns were published in some detail (Johns 1950), while the other expeditions have produced only preliminary short reports (Amiran - Eitan 1973; Sivan - Solar 1994; Geva 2000). Excavations by the four expeditions have shown that the First Hasmonaean Wall exposed in the Citadel had been massively remodeled and reinforced in Herod's days and new towers had been incorporated in it. These changes were interpreted as resulting from the construction of the palace to the east of the wall.

20 The salvage excavations inside the Qishle Compound were conducted by Re'em on behalf of the Israeli Antiquity Authority between 2000-2001. The final report of the excavation was recently published: Re'em 2018.

21 Excavations in the Armenian School and along the western line of city wall were conducted by Broshi and Bahat between 1970-1971 and later by Broshi between 1973-1978. These excavations have produced so far only preliminary short reports (Bahat - Broshi 1976; Broshi 1976; Broshi - Gibson 1994). These excavations have also shown a thickening of the Hasmonaean city wall in the time of Herod.

22 Excavations in the Armenian Garden were led by Tushingham and Kenyon between 1962-1967. Tushingham published the final report (Tushingham 1985). 
identified with certainty with the superstructure of this immense building. Nevertheless, the excavators have suggested that several walls unearthed in these excavations, belong to the foundations of the palace, which apparently was built, at least in part, on top of a large levelled podium.

During their excavations inside the Citadel in 1968-1969, Amiran and Eitan have exposed a series of walls supporting massive earthen fills abutting the eastern (inner) face of the "First Wall" (opposite the "Middle Tower"). The excavators dated these walls to Herod's time and identified them as foundation walls for Herod's palace. ${ }^{23}$ In his excavations inside the Qishle in 2000-2001, Re'em has exposed two parallel walls oriented along a north-south axis for a length of $41 \mathrm{~m}$ (the western wall $1.8 \mathrm{~m}$ wide and the eastern wall $3 \mathrm{~m}$ wide) and preserved to a considerable height. The walls were dated to the time of Herod based on the finds in the foundation trench of both walls that included sherds typical of the second half of the first century BCE. ${ }^{24}$ The walls served as retaining walls for the fills that were deposited between them, and together they created a raised artificial podium, apparently the base for Herod's palace. ${ }^{25}$ Remains of this huge platform were also found in the excavations conducted by Bahat and Broshi in the Armenian School, south of the Qishle. ${ }^{26}$

Alongside the retaining walls and fills that were attributed to the palace's podium, two more features exist that seem to relate to the palace, both carved into the bedrock. During their excavations in the eastern moat of the Citadel in 1980-1988, Sivan and Solar have unearthed an impressive rock-cut pool with wide steps leading to it (Fig. 2), which they dated to the Byzantine period, as well as a stepped cut installation, which they dated to the Hasmonaean period and suggested it was later incorporated into Herod's palace. ${ }^{27}$ The close proximity of the two installations to the retaining walls exposed inside the Qishle and the similar orientation led other scholars to suggest that the two installations, together with other water channels known from the vicinity created a large water system that was part of Herod's palace. ${ }^{28}$ The existence of a large water pool inside the palace

23 Amiran - Eitan 1973, 214-216. These excavations have also revealed small portions of walls (some covered with painted plaster), which the excavators have interpreted as the superstructure of Herod's palace. However, Netzer $(2006,130)$ doubted that these walls belonged to palace proper and suggested they were part of barracks or service wings adjacent to the palace.

24 The western of the two retaining walls (W3) abutted the eastern (inner) face of the Hasmonaean "First Wall," whose height had been intentionally reduced to be covered by the fills of the Palace. Herod, then, widened the city wall to the west, creating a new massive wall with towers to protect the palace: Re'em $2019,140$.

25 Re'em 2018, 38-53; Re'em 2019, 141.

26 Bahat - Broshi 1976, 55-56. The excavations conducted by Kenyon and Tushingham in the Armenian Garden have also exposed remains dating to Herod's time. Tushingham $(1985,25-27)$ interpreted the remains of a massive wall to be Herod's western city wall that served also as a retaining wall for the podium. However, Gibson (1987, 87-93) has managed to show that this wall is actually part of the Hasmonaean "First Wall." Tushingham (1985, 28-32, 41-42) has also uncovered a system of walls and fills from the time of Herod, which he has interpreted as remains from the palace's podium, as well as fragments of molded plaster, which he identified as coming from the superstructure. However, based on the dimensions and location of these walls, Re'em $(2018,243)$ believes that they belong to wealthy dwellings, similar to the ones, exposed by Broshi (1976, 57-58) on Mount Zion, and not to Herod's palace.

27 Sivan - Solar 1994, 175.

28 Re'em 2018, 243. 
accords with both Josephus description of the palace (see below) and the frequent use of pools in all other excavated Herodian palaces. ${ }^{29}$

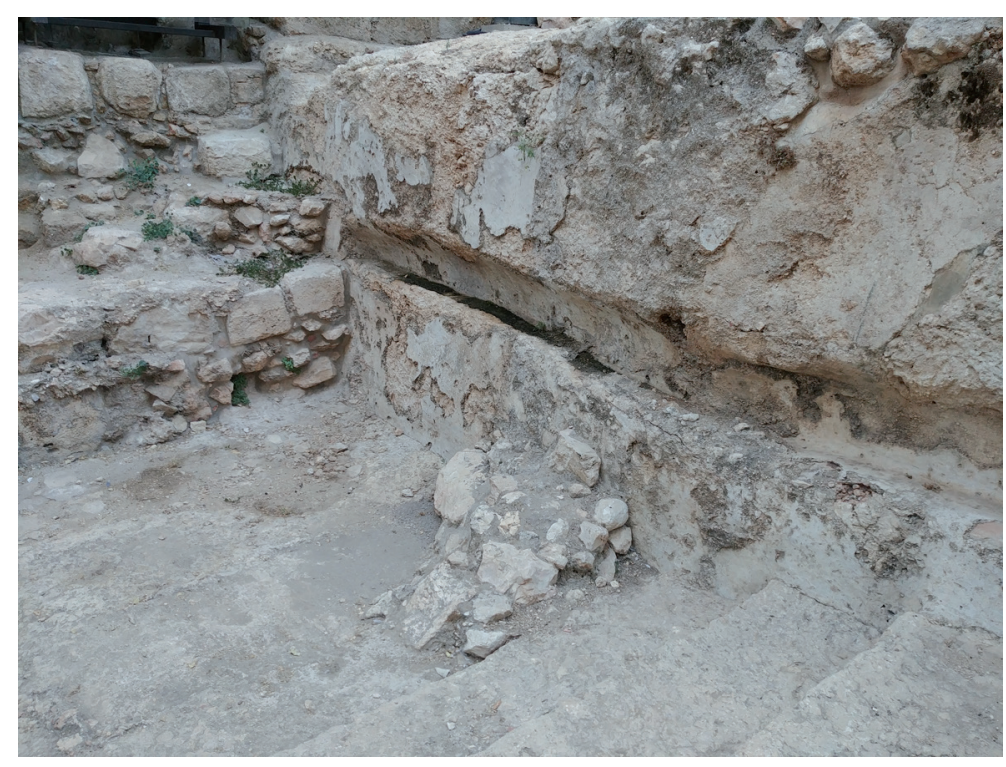

Fig. 2. A water channel and wide steps going down to the rock-cut pool in the eastern moat of the Citadel (Photo by Orit Peleg-Barkat)

The second rock-cut feature that was attributed to Herod's palace is a channel cut to a depth of $5 \mathrm{~m}$, running east-west, and contemporary with the retaining walls exposed in the Qishle excavations. Broshi and Gibson already exposed another section of this channel in the early $1980 \mathrm{~s},{ }^{30}$ but only the recent excavations in the Qishle reaffirmed its Herodian date. According to the excavator, the channel is part of an elaborate drainage system carrying runoff from the center of the palace area westward toward the Hinnom valley. ${ }^{31}$

Interpreting the remains documented in the various archaeological excavations in the premises of the Citadel, the Ottoman Qishle, Armenian School and Armenian Garden in light of Josephus' testimony, a vague picture of Herod's palace emerges. We can positively say that Herod built his main palace on the northwestern part of the Southwestern Hill of Jerusalem. He protected it on the north by three massive and decorated towers and on the west by a new reinforced outline of the "First Wall." The northern and western boundaries of the palace are, therefore, known, although it remains unclear whether the three towers were an integral part of the palace or were separate from it. ${ }^{32}$ The palace had

29 E.g., in Herodium, Caesarea Maritima, Jericho, and Masada. It were already the Hasmonaeans, Herod's predecessors, which integrated swimming pools in their palaces, see: Netzer 1985.

30 Broshi - Gibson 1994: 153. See also Gibson 2007: 29*-33*.

31 Re'em 2018, 53-62; Re'em 2019, 140-141.

32 Later construction activities in the area between the Tower of David and the Qishle obstruct any possibility for archaeology to provide a suitable answer: Re'em 2018, 245. 
elaborate systems for collecting and draining water, as well as water recreational installations. Massive retaining walls and earthen fills created a large levelled podium serving as foundation for the construction of the palace.

Two main questions remain relating to the plan and dimensions of the palace. As for the plan and layout of the palace, the archaeological remains do not provide, unfortunately, any clues. As for the dimensions of the palace, scholarly opinions differ considerably. While some scholars have limited the palace to the area of present day David Citadel, ${ }^{33}$ others have suggested that the palace have extended over most of the southwestern hill, continuing in the south up to the line of the Ottoman city wall or close to $\mathrm{it}^{34}$ and in the east up to Jewish Quarter. ${ }^{35}$

\section{Josephus' Description of Herod's Western Palace in Jerusalem}

Josephus' texts and especially his accounts on Herod's construction projects are dotted with exphrases dedicated to detailed descriptions of his palaces and public buildings. ${ }^{36}$ Still, one of the longest and most detailed descriptions refers to the western palace of the king in Jerusalem, to whom Josephus devotes a long section in the fifth book of his Bellum Judaicum (BJ 5.177-181):

... indeed, in extravagance and equipment no building surpassed it. It was completely enclosed within a wall thirty cubits high, broken at equal distances by ornamental towers, and contained immense banqueting-halls and bed-chambers for a hundred guests. The interior fittings are indescribable - the variety of the stones (for species rare in every other country were here collected in abundance), ceilings wonderful both for the length of the beams and the splendor of their surface decoration, the host of apartments with their infinite varieties of design, all amply furnished, while most of the objects in each of them were of silver or gold. All around were many circular cloisters, leading one into another, the columns in each being different, and their open courts all of greensward; there were groves of various trees intersected by long walks, which were bordered by deep canals, and ponds everywhere studded with bronze figures $(\chi \alpha \lambda \kappa о v \rho \gamma \eta \mu \alpha ́ \tau \omega v)$, through which water was discharged, and around the streams were numerous cots for tame pigeons.

33 Simons 1952, 295, Fig. 40; Parrot 1957, 17.

34 E.g., Bahat 1990, 35; Geva 1993, 718; Ben-Dov 2002, 113. Re'em has recently suggested that the southern border of the palace lies on the axis of a wall oriented east-west exposed in Broshi and Bahat's excavation (W13; Re'em 2018, 246).

35 For the various proposals and references, see Re'em 2018, 246. Re'em himself suggests, like several other scholars, that the eastern border of the palace was along the line of current Armenian Patriarch Street and did not extend further east. However, since the analysis of the finds from Avigad's excavations along the eastern part of the Southwestern Hill (the Jewish Quarter) have shown that the area only became intensively populated in the first century CE (according to Geva; oral correspondence), it seems that there was no significant obstacle that could prevent Herod from spreading his palace over a larger area. An example for this can be seen in the "Burnt House" that was excavated by Avigad in the Jewish Quarter. The house was built directly on remains from the First Temple period (Iron Age) in the first century CE: Geva 2010,78 .

${ }^{36}$ For Josephus' exphrasis of the Royal Portico that Herod built along the southern flank of the Temple Mount, see: Peleg-Barkat 2017, 91-120. 
The following list summarizes the architectural data within Josephus' text:

1. The palace is enclosed within a high wall with towers.

2. It has elaborately decorated banqueting halls.

3. It includes numerous bedchambers.

4. The interior decoration uses colored imported stones.

5. Long decorated wooden beams supported the ceilings.

6 . There is a great variety in the design of the various spaces.

7. Many porticoes exist in the palace, each with a different type of columns.

8. Large gardens with trees, walkways and open channels existed in the palace.

9. Water pools with fountains, in which the water came out of bronze figures, were scattered in the palace's gardens.

10. Cots for doves (columbaria) were also built in these gardens.

For most of these architectural components, we can easily find comparanda in other Herodian palaces. Thus, for example, Herod's palaces in Masada, Machaerus and the other Desert Fortresses were all protected by a circuit wall and towers, and so was the Antonia Citadel and Herodium Palace-Fortress mentioned above. ${ }^{37}$ Similarly, all of Herod's palaces contained triclinia and banqueting halls, most elaborate of which are the ones in the lower terrace of Masada's Northern Palace $(10.3 \times 9.0 \mathrm{~m})$ and in the Northern Wing of Herod's Third Palace in Jericho (triclinium B70; $28.9 \times 18.9 \mathrm{~m}$ ). ${ }^{38}$ Large gardens were excavated in Herod's winter palaces in Jericho and were also virtually identified in the palaces of Herodium and Masada. ${ }^{39}$ Columbaria meant to provide with fertilizing material for the gardens were excavated in Jericho, Cypros and Masada (Fig. 3).$^{40}$ The reference in Josephus' text to the extensive use of imported stones from various countries probably refers to opus sectile floors that paved many of the major halls in Herod's construction projects. ${ }^{41}$

An interesting characteristic of the palace in Jerusalem mentioned by Josephus is the use of different types of columns in the porticoes that adorned the palace. This assertion finds a vivid demonstration in the northern wing of Herod's Third Palace in Jericho, where each of the three main spaces - triclinium B70 and the two peristyle courtyards B64 and B55-were decorated with a different set of columns that differ, not just in the order of the capitals, but also in color and size. The columns of peristyle courtyard B64 (42 $\mathrm{cm}$ in diameter) were coated on their lower third with red plaster and on their upper

37 Foerster 1995, 209-213; Netzer 2006, 36-39, 183-186, 202-217.

38 Netzer 1981b; Netzer 2006, 31-32, 63-64; Foerster 1995, 179-190. A similarly large triclinium also existed in Herod's First Palace in Jericho (Hall 33).

39 For a recent summary and discussion on Herodian gardens, see: Gleason - Bar-Nathan 2013.

40 Pigeon rearing was common in the ancient Levant, particularly in Palestine, from early times. Talmudic sources that mention Herodian Doves (ונים הורדוסיות') attest apparently to a special breed developed by Herod: Oren 1968; Foerster 1995, 219-223.

41 In Herodian palaces, evidence for the implementation of opus sectile floors - whether in situ tiles, tile impressions in the mortar, and/or scattered tiles and fragments - was found in triclinia and bathhouses. The materials and tile patterns varied from site to site, but all would have been impressive, both artistically and architecturally. Evidence of opus sectile floors has been recovered in Herod's palaces at Paneas (Caesarea Philippi), Caesarea Maritima, Jericho, Cypros, Herodium, Machaerus, Masada, as well as on the Temple Mount. For a general discussion and references, see: Snyder - Avraham 2013, 178-202; Bar-Nathan - Snyder 2019. 


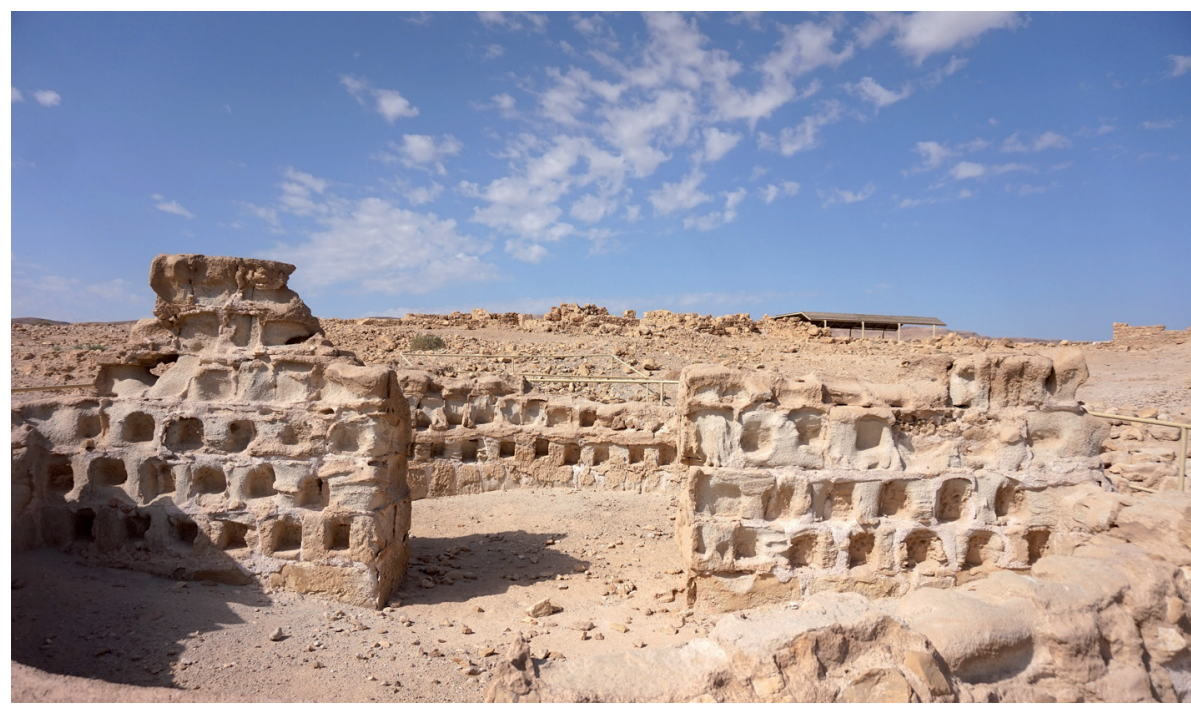

Fig. 3. The Columbarium tower at Masada (Photo by Tiia Monto, Wikimedia Commons)

parts with 20 flutings with concave surfaces between the fillets, and bore Ionic capitals molded in stucco. The columns of courtyard B55 (43 cm in diameter) were coated with alternately red and black plaster on their lower third and 20 Ionic flutings on their upper parts, and bore stone carved Corinthian capitals. The columns of triclinium B70 (c. $1 \mathrm{~m}$ in diameter) stood on top of built and plastered pedestals and carried Corinthian capitals of which only small fragments survived. ${ }^{42}$

Perhaps the only unique feature in the description of the palace is the inclusion, alongside water pools in the palace's garden, of fountains, ${ }^{43}$ in which the water was discharged through bronze figures ( $\chi \alpha \lambda \kappa o v \rho \gamma \eta \mu \alpha ́ \tau \omega v)$, namely bronze sculptures. This implies the use of figurative art in Herod's palace. Without getting into the question of how Herod perceived his own Jewishness, ${ }^{44}$ the decoration of his palaces normally exhibits avoidance from figural depictions, in accordance with the second commandment and with Jewish norms of his time..$^{45}$ Nevertheless, several exceptions to Herod's general abstention from depicting animals and human figures do exist. The most striking examples were

42 Peleg - Rozenberg 2008; Peleg-Barkat 2015.

43 On the use of fountains in Herod's palaces, see: Stiebel 2015.

44 See, for example, Kokkinos (1998, 86-139) and Fuks (2002), who portray Herod as a pragmatic Hellenized king, who was ready to break the Jewish law to achieve his goals, versus Regev (2010), who claims that despite being an enthusiast agent of the Greco-Roman culture, Herod maintained his native Jewish identity. Jewish norms and traditions have clearly influenced many aspects of Herod's constructions. Examples for this influence can be seen in his enormous investment in the rebuilding of the Temple and the enlargement of the Temple Mount compound, his avoidance from building pagan temples within the boundaries of his kingdom (other than the temples to the ruler-cult of Augustus), as well as the transformation of the frigidaria pools in the Roman-type bathhouses he incorporated in his palaces into ritual baths: Reich 2013, 248-249.

45 On the Jewish avoidance from depicting human figures during the Second Temple Period, from the days of the Hasmonaeans onward, see: Levine 2005; Tsafrir 2015. Also telling is the construction of a nymphaeum (perhaps part of a public triclinium or a Prytaneion of sorts) to the west of the Temple Mount in the 
unearthed at Herodium. The walls of the reception area above the summa cavea of the small theatre on the slopes of the Mountain-Palace Fortress were decorated with framed pictures on the upper part of the wall, between decorated Corinthian pilasters. ${ }^{46}$ The pictures contained Nilotic landscapes with vegetation, architecture, ships bearing armed men, animals such as goats, dogs, crocodiles, bulls and even a faun. ${ }^{47}$ In the bathhouse of Lower Herodium, a large, imported, three-legged marble basin (labrum) was found, decorated with winged female figures and Sileni masks. ${ }^{48}$ Also relevant is Josephus testimony about the golden eagle that Herod erected over the great gate to the Temple ( $B J$ 1.650). Therefore, it seems that despite his normal adherence to Jewish norms, in some instances Herod strayed from the Jewish abstention from human and faunal depictions. Apparently, one of these deviations occurred in his palace in Jerusalem.

\section{Monumental Ionic Columns from the Southwestern Hill and Herod's Palace}

Several column bases, column drums, an almost complete Ionic capital and a dozen fragments of several other Ionic capitals of similar size and style were found during Avigad's excavations in the center of the Jewish Quarter. ${ }^{49}$ The fragments were retrieved from Area Q, at the southeastern corner of the Hurva Square, and Area H, situated a short distance to the west of Area $\mathrm{Q}$. While the fragments from area $\mathrm{H}$, as well as some of the fragments found in Area Q lack clear archaeological contexts, most of the Ionic capital fragments from area $\mathrm{Q}$, as well as one column drum fragment, were found incorporated in secondary use into the walls of a Byzantine period cistern (Fig. 4). The cistern was cut into the central lower part of an exceptionally large miqweh (ritual bath), dated to the end of the Second Temple period. ${ }^{50}$

days of Herod, in which the water sprouted out of Corinthian capitals crowning the pilasters that adorned the fountain's meandering back wall: Patrich - Weksler-Bdolah 2016.

46 The reception area includes a 7 by $8 \mathrm{~m}$ wide decorated hall at the back of the summa cavea, overlooking the stage area of the theatre and flanked by two smaller rooms. See: Netzer et al. 2010, 84-108; Netzer et al. 2013, 126-161.

47 For discussion on these paintings and photographs, see: Rozenberg 2013, 174-189. Different scholars related the framed pictures to sacro-idyllic (Rozenberg 2013; Rozenberg 2014), historiographic (Kahanov et al. 2015; Rozenberg 2017) and mythological scenes (Ovadiah - Turnheim 2013).

48 Netzer et al. 2013, 144-145.

49 Avigad 1983, 161-162, Figs. 178-181. The excellent preservation state of the fragments from area $\mathrm{H}$ enabled their anastylosis (reconstruction using the original pieces) and re-erection at Batei Mahseh Square, in the Old City. The fragmented capital from Area Q was recently reconstructed by the Israel Museum laboratory to allow its presentation in the 2013 exhibition on the Final Journey of Herod (Peleg-Barkat - Ben Haim 2017; Peleg-Barkat - Geva - Reich 2017).

50 The miqweh had stairs coated with grey plaster ascending from all four sides. During the Byzantine period, the miqweh was converted into a cistern; its bottom part was cut in order to reach deeper into the ground and the bedrock below. The $1 \mathrm{~m}$. wide walls of the cistern, supporting its vaulted roof (found in ruin), were built on top of the miqweh's lower remaining stairs. The cistern's walls were built of stones of varying sizes, some of which were taken from earlier buildings. Among these stones were also many fragments of different sizes of an Ionic capital. It seems that the capital was deliberately broken into pieces to facilitate its incorporation into the walls: Reich 2013, 92-95; Geva 2015. 


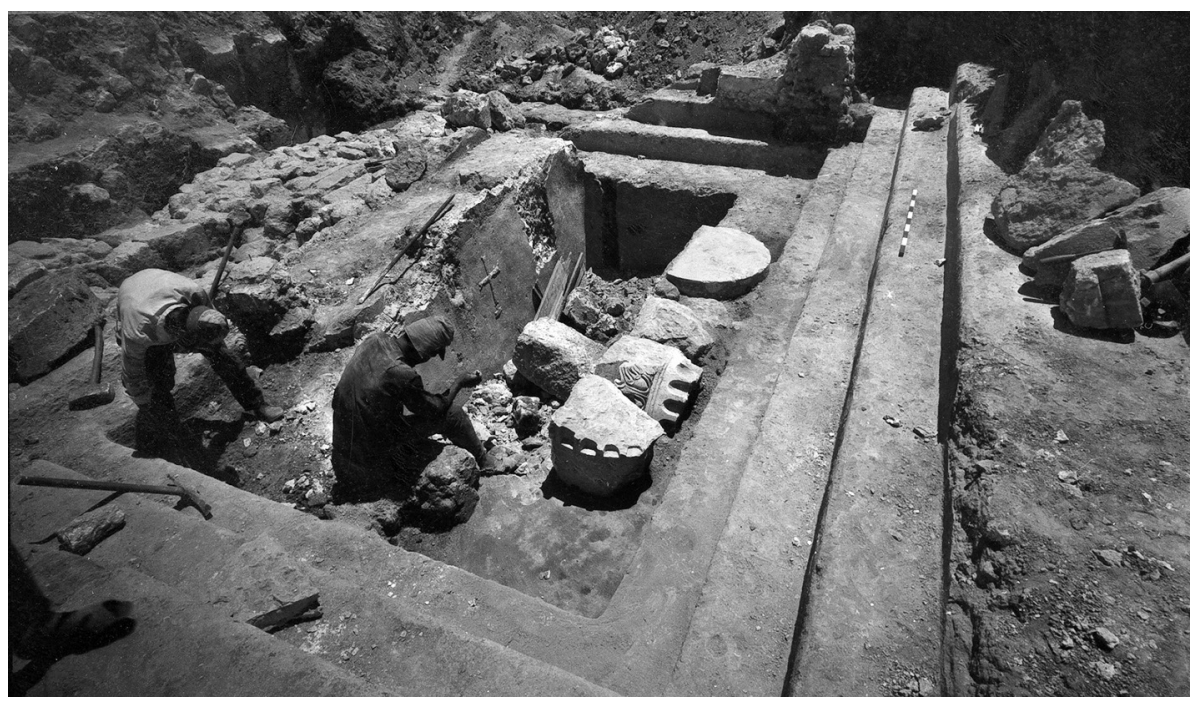

Fig. 4. Column drum and Ionic capital fragments found incorporated in secondary use into the walls of a Byzantine period cistern that was built on top of a late Second Temple period miqweh in Area Q of the Jewish Quarter Excavations (Courtesy of Hillel Geva, The Jewish Quarter Excavations)

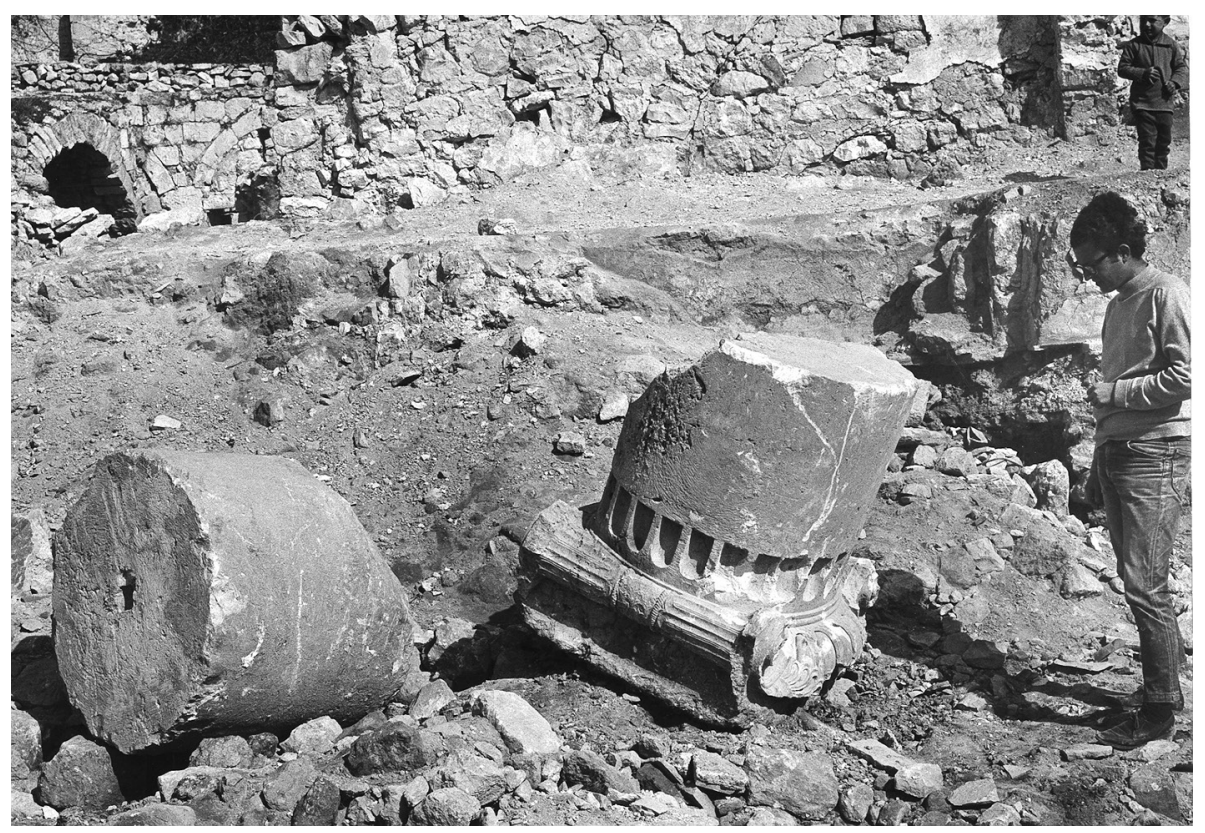

Fig. 5. The almost complete Ionic capital and column drum found in area $\mathrm{H}$, the Jewish Quarter of Jerusalem (Courtesy of Hillel Geva, The Jewish Quarter Excavations) 
The fragments relate to $c .1 \mathrm{~m}$. in diameter Ionic columns (Fig. 5). Their similar monumental dimensions (reconstructed height of 8-9 m), common stylistic characteristics, and the fact that they were found in a rather short distance from one another, suggest that they all belong to one series of columns that originates from a single monumental building that once stood on the Southwestern Hill of Jerusalem. Several of the fragments' features, as well as their carving style, point to a date in the late 1st century BCE or the 1 st century CE. One of these features is the fact that on two of the drums ${ }^{51}$ unchiseled small square knobs have been preserved. Such knobs are in accordance with a contemporary architectural fashion that was prevalent during the late Second Temple period in Jerusalem. These protuberances were probably used initially to assist in hoisting the stones into place using a crane. However, the fact that so many such knobs remained unchiseled, tells us that they became an intentional and even desired decoration. Similar knobs on column drums were found in Jerusalem, for example, in the Western Wall tunnel, in the Pool of Siloam and in the Tomb of Queen Helene of Adiabene ("Tomb of the Kings"). ${ }^{52}$ Another indicative characteristic is the appearance on the neck of the Ionic capitals, at a distance of $4.5-5 \mathrm{~cm}$. below the echinus, of a series of small rectangular depressions concave on their upper side, reminiscent of the sulci of unfinished flutings (Fig. 6). A similar decoration appears on the necks of the Ionic capitals on the facade of the Tomb of Zechariah in the Kidron Valley (Fig. 7), as well as on three capitals found to the south and southwest of the Temple Mount, ${ }^{53}$ and is unique to the Herodian architecture of Jerusalem.

The architectural fragments, and especially the Ionic capitals, are of excellent workmanship and they undoubtedly represent some of the finest examples of Herodian architecture in Jerusalem. Their grand dimensions ${ }^{54}$ and exquisite workmanship suggest that they originate in a public or royal major building.

Since none of the pieces were found in situ in their original context, it is impossible to identify with certainty the structure they have originally decorated. However, it is possible to cautiously suggest where they come from. Reich has recently suggested that

51 Peleg-Barkat - Ben Haim 2017, Plate 3.1:2, 4.

52 Similar knobs on building stones are still visible on the enclosure walls of the Temple Mount and the Cave of Patriarchs in Hebron. Outside Jerusalem, we find similar examples in the peristyle at the FortressPalace of Herodium, Bet She'an, Horvat 'Eleq in Ramat Hanadiv and at the oval plaza in Jerash: Peleg-Barkat 2007, 268, Figs. 168, 341-346.

53 Avigad 1954, Fig. 47; Peleg-Barkat 2007, nos. 1031-1033. Recent conservation-work conducted south of the Temple Mount have brought to light another fragment of an Ionic capital carved with such depressions on its neck: Baruch - Reich - Sanhaus 2016, 51-52, Fig. 19. It seems that the inspiration for this decoration came from the practice of carving the flutes on the upper edge of a column, normally carved in one block together with its capital, prior to hoisting it up to its final position. Only when an entire column stood in place was scaffolding erected and fluting completed along the column's entire height, in accordance with the sulci carved below the capital: Avigad 1983, 161. Several examples of standing columns with unfinished column flutes are found in Hellenistic Asia Minor, for example at the Temple of Artemis in Sardis and the Temple of Apollo at Didyma, as well as in the Royal palace at Pella, capital of ancient Macedonia. For references and further arguments supporting the dating of the Ionic columns to the Herodian period, see: Peleg-Barkat - Ben Haim 2017, 73-74.

54 An examination of column diameters common in Herodian Judea shows that, apart from the columns of the temples of Roma and Augustus at Caesarea and Sebaste and the columns originating from the Royal Portico, all other columns range in diameter from 30 to $70 \mathrm{~cm}$ : Peleg-Barkat - Ben Haim 2017, 71. 


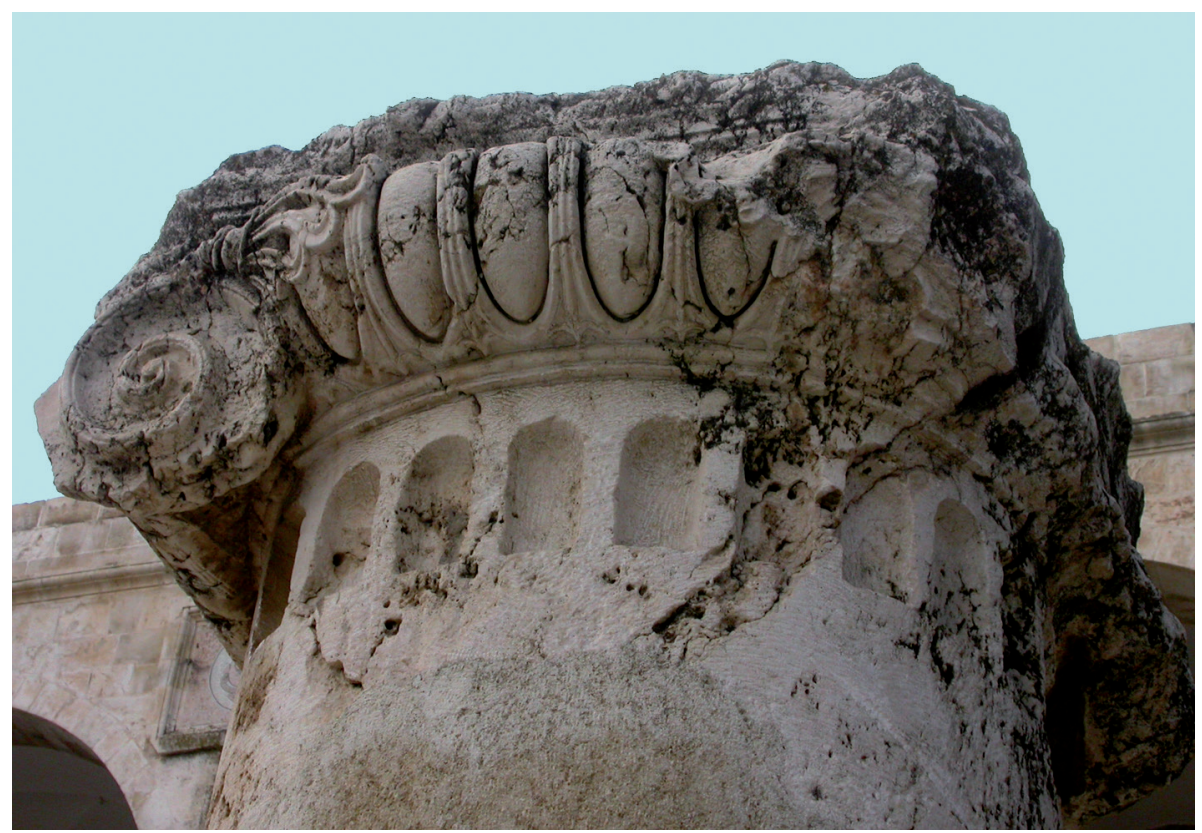

Fig. 6. Close-up on the Ionic capital found in area H (Photo by Orit Peleg-Barkat)

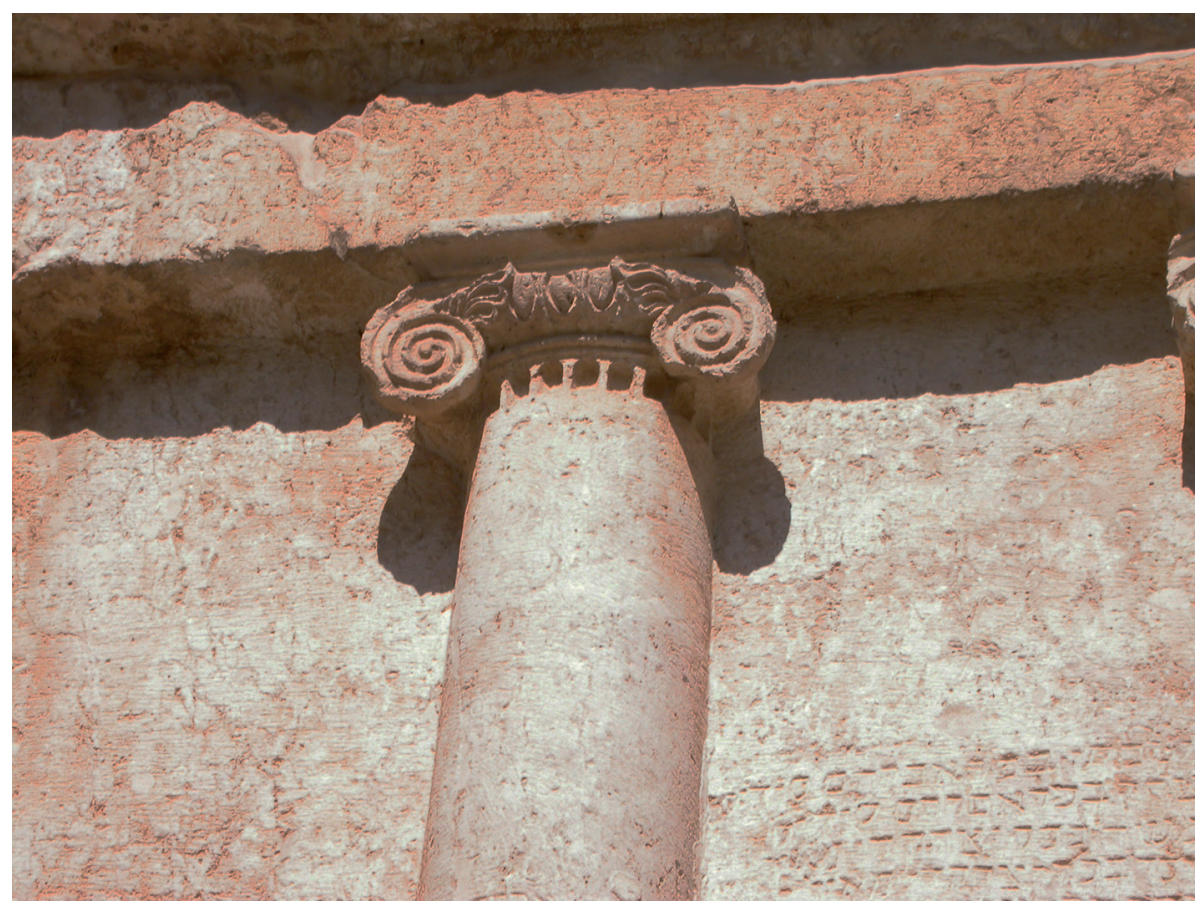

Fig. 7. The Ionic capital of an engaged column on the western façade of the Tomb of Zechariah in the Kidron Valley, Jerusalem (Photo by Orit Peleg-Barkat) 
the Ionic columns came from the Royal Portico that according to Josephus was erected by Herod along the southern flank of the Temple Mount. ${ }^{55}$ However, since Josephus' description of this structure explicitly mentions the use of Corinthian capitals, and since more than 60 fragments of Corinthian capitals were found at the foot of the Temple Mount (and according to their style and measurements can be easily attributed to one monumental structure), there seems no plausible reason to doubt this specific detail in Josephus' description. ${ }^{56}$ Similarly, there is no logic in the proposal that the monumental Ionic columns were brought all the way up from the Royal Portico on the Temple Mount to be used in the walls of a Byzantine-period cistern.

It seems more sensible to suggest that the Ionic columns originate in Herod's famous palace that was built in the Upper City. It should be stated that similar large column drums and other architectural pieces were found during the excavations in David Citadel. ${ }^{57}$ Especially noteworthy are the two column bases found at the moat of the citadel (reused as cistern mouths in later periods), whose upper diameter $(1.05$ and $1.10 \mathrm{~m})$ corresponds well with the dimensions of the Ionic columns from Avigad's excavations, and whose style of carving and proportions are also very much reminiscent of the column bases from the Jewish Quarter.

Another argument in favor of ascribing the monumental Ionic columns to Herod's palace is the fact that together with the Ionic capital fragments that were incorporated into the walls of the Byzantine-period cistern in Area Q, the excavators have also found a large sculptured lion head, dated according to its style to the Herodian period (Fig. 8).$^{58}$ As mentioned above, Judaism of the late Second Temple period, from the time of the Hasmonaeans onward, held a negative approach towards figurative art, in accordance with the Second Commandment. Therefore, such figural sculptures and other figural displays are very rare in Jerusalem and other Jewish settlements in Judaea. Nevertheless, in Herod's constructions project we see several exceptions to this rule, where he does make use of human and faunal depictions (see above). It seems therefore, that, if indeed the sculpted lion head is Herodian in age, it could only possibly have originated from Herod's palace.

55 Reich 2017.

56 The Corinthian capitals are mentioned, alongside other architectural components, in a way that is uncharacteristic of Josephus' writing and may hint at the incorporation of a source with a greater familiarity of classical architecture: Peleg-Barkat - Geva 2017; Peleg-Barkat 2017, 94-95.

57 Amiran and Eitan $(1973,216)$ mention an Ionic capital and a column drum with mason's mark found in the Herodian stratum, but unfortunately they have not published a photograph or drawing of the items. Sivan and Solar $(1994,175)$ also mention many column drums found in the Citadel's moat. However, they do not mention their size or any other details.

58 Palistrant Shaick 2017. 


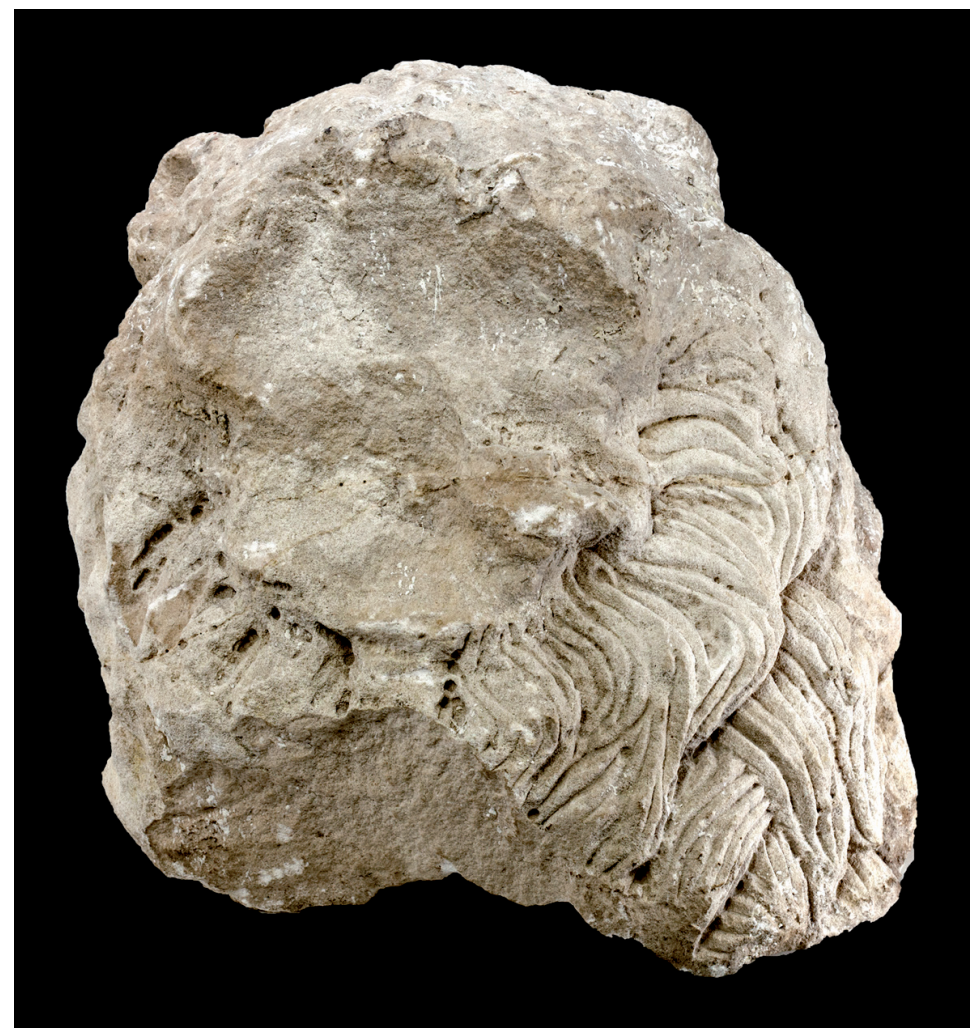

Fig. 8. A sculpted lion head found incorporated in secondary use into a Byzantine period cistern in area Q, the Jewish Quarter of Jerusalem (Courtesy of Hillel Geva, The Jewish Quarter Excavations)

\section{Summary}

Information gathered from recent excavations, as well as from publications of previous excavations that are now finally seeing light, enhance our knowledge about the ancient topography of Jerusalem and provide us with a better appreciation of its past. The excavations in the Qishle that have recently been published firmly proves the Herodian date for the massive substructure of Herod's western palace in Jerusalem. While the northern and western boundaries of the palace are clearer now than before, it remains for us to reconstruct the extent to which the palace continued eastward. The group of monumental Ionic columns, alongside a sculpted head of a lion, found in the Southwestern Hill, just east of the Byzantine period cardo, if indeed it belong to Herod's palace (currently no better candidate exists), implies that the palace spread considerably east. It is hard to assume that these massive columns were taken from a far, only to be incorporated in the walls of a Byzantine period cistern. We may suggest that in the turbulent events of the siege and conquest of the city between 66 and $70 \mathrm{CE}$, the columns were toppled down from the eastern part of the palace, maybe further rolling down hill, until they have reached the spot where they were unearthed 2000 years later. 
Amiran, R., Eitan, A. (1973), Excavations in the Citadel, Jerusalem 1968-1969 (Preliminary Report), Eretz Israel 12: 213-218 (Hebrew).

Avigad, N. (1954), Ancient Monuments in the Kidron Valley, Jerusalem (Hebrew).

Avigad, N. (1983), Discovering Jerusalem, Nashville.

Avi-Yonah, M. (1989), Pictorial Guide to the Model of Ancient Jerusalem at the Time of the Second Temple, revised by Y. Tsafrir, Jerusalem.

Bahat, D. (1981), David's Tower and Its Name in Second Temple Times, Eretz-Israel 15: 396-400 (Hebrew).

Bahat, D. (1990), The Illustrated Atlas of Jerusalem, New York.

Bahat, D., Broshi, M. (1976), Excavations in the Armenian Garden, in: Y. Yadin (ed.), Jerusalem Revealed: Archaeology in the Holy City 1968-1974, Jerusalem: 55-56.

Bar-Nathan, R., Snyder, F. (2019), Is The Opus Reticulatum Building at Banias a Palace of Herod the Great? New Insights after Analyzing Its Opus Sectile Floor, in: O. Peleg-Barkat et al. (eds.), Between Sea and Desert: On Kings, Nomads, Cities and Monks, Essays in Honor of Joseph Patrich, Tzemach: 23-40.

Baruch, Y., Reich, R., Sanhaus, D. (2016), The Temple Mount: Results of the Archaeological Research of the Past Decade, in: G. D. Stiebel et al. (eds.), New Studies in the Archaeology of Jerusalem and Its Region 10: 33-54 (Hebrew).

Ben-Dov, M. (2002), Historical Atlas of Jerusalem, New York.

Benoit, P. (1975), The Archaeological Reconstruction of the Antonia Fortress, in: Y. Yadin (ed.), Jerusalem Revealed: Archaeology in the Holy City 1968-1974, Jerusalem: 87-89.

Braund, D. C. (1984), Rome and the Friendly King: The Character of Client Kingship, London.

Broshi, M. (1976), Excavations in the House of Caiaphas, Mount Zion, in: Y. Yadin (ed.), Jerusalem Revealed: Archaeology in the Holy City 1968-1974, Jerusalem: 57-60.

Broshi, M., Gibson, S. (1994), Excavations along the Western and Southern Walls of Old City of Jerusalem, in: H. Geva (ed.), Ancient Jerusalem Revealed: Reprinted and Expanded Edition, Jerusalem: $147-155$.

Crighton, J. (2009), Herod's Contemporaries in Britain and the West, in: D. M. Jacobson, N. Kokkinos (eds.), Herod and Augustus: Papers Presented at the IJS Conference, $21^{\text {st }}-23^{r d}$ June 2005, Leiden: 361-381.

Foerster, G. (1995), Masada V: Art and Architecture, The Yigael Yadin Excavations 1963-1965, Final Reports, Jerusalem.

Foerster, G. (1996), Hellenistic and Roman Trends in the Herodian Architecture of Masada, in: K. Fittschen, G. Foerster (eds.), Judaea and the Greco-Roman World in the Time of Herod in the Light of the Archaeological Evidence: Acts of a Symposium (Abhandlungen der Akademie der Wissenschaften in Göttingen, Philologischhistorische Klasse 215), Götingen: 55-72.

Fuks, G. (2002), Josephus on Herod's Attitude towards Jewish Religion: The Darker Side, Journal of Jewish Studies 53: 238-245.

Geva, H. (1981), The 'Tower of David' - Phasael or Hippicus?, IEJ 31: 57-65.

Geva, H. (1993), Jerusalem: The Second Temple, in: E. Stern (ed.), The New Encyclopedia of Archaeological Excavations in the Holy Land, vol. 2, Jerusalem: 717-757.

Geva, H. (2000), Excavations at the Citadel of Jerusalem, 1976-1980, in: H. Geva (ed.), Ancient Jerusalem Revealed: Reprinted and Expanded Edition, Jerusalem: 156-167.

Geva, H. (2010), The "Burnt House" in Light of the Publication of the Final Report, in: D. Amit et al. (eds.), New Studies in the Archaeology of Jerusalem and Its Region 4: 74-83.

Geva, H. (2015), A Second Temple Period Miqveh with a Surrounding Staircase in the Jewish Quarter, in: E. Baruch, A. Faust (eds.), New Studies on Jerusalem, vol. 21, Ramat Gan: 109-121 (Hebrew). 
Gibson, S. (1987), The 1961-67 Excavations in the Armenian Garden, Jerusalem, Palestine Exploration Quarterly 119: 81-96.

Gibson, S. (2007), Suggested Identification for 'Betso' and the 'Gate of the Essens' in the Light of Magen Broshi's Excavations on Mount Zion, in: J. Patrich, D. Amit (eds.), New Studies in the Archaeology of Jerusalem and Its Region 1: 29*-33*.

Gleason, K., Bar-Nathan, R. (2013), The Paradaisoi of the Hasmonean and Herodian Palaces at Jericho, in: R. Bar-Nathan, Y. Gärtner (eds.), Hasmonean and Herodian Palaces at Jericho - Final Reports of the 1973-1987 Excavations, vol. V: The Finds from Jericho and Cypros, Jerusalem: 317-366.

Jacobson, D. M. (2001), Three Roman Client Kings: Herod of Judaea, Archelaus of Cappadocia and Juba of Mauretania, Palestine Exploration Quarterly 133: 22-23.

Japp S. (2000), Die Baupolitik Herodes'des Grossen: Die Bedeutung der Architektur für die Herrschaftslegitimation eines römischen Klientelkönigs, Rahden/Westf.

Johns, C. N. (1950), The Citadel, Jerusalem: Summary of Work since 1934, Quarterly of the Department of Antiquities in Palestine 14: 121-190.

Josephus Flavius, Jewish Antiquities (books XVI-XVII), translated by R. Marcus, A. Wikgern (Loeb Classical Library no. 410), Cambridge, MA 1963.

Josephus Flavius, The Jewish War (books I-IV), translated by H. S. J. Thackeray (Loeb Classical Library nos. 203, 487), Cambridge, MA 1927.

Kahanov, Y., Cvikel, D., Rozenberg, S. Kalman, Y., Chachy, R., Porat, R. (2015), The Ships from Herodium, The Mariner's Mirror 101: 262-271.

Kaizer, T., Facella, M. (eds.) (2010), Kingdoms and Principalities in the Roman Near East, Stuttgart.

Kasher, A., Witztum, E. (2007), King Herod: A Persecuted Persecutor: A Case Study in Psychohistory and Psychobiography, (Studia Judaica 36), Berlin-New York.

Kokkinos, N. (1998), The Herodian Dynasty, Sheffield.

Kropp, A. J. M. (2013), Images and Monuments of Near Eastern Dynasts, 100 BC-AD 100, Oxford.

Landau, T. (2006), Out-Heroding Herod: Josephus, Rhetoric, and the Herod Narratives, (Ancient Judaism and Early Christianity 63), Leiden-Boston.

Levine, L. I. (2005), Figural Art in Ancient Judaism, Ars Judaica 5: 9-26.

Levine, L. I., Netzer, E. (1986), Excavations at Caesarea Maritima 1975, 1976, 1979 - Final Report, (Qedem 21), Jerusalem.

Lichtenberger, A. (1999), Die Baupolitik Herodes des Großen, Wiesbaden.

Lichtenberger, A. (2009), Herod and Rome: Was Romanization a Goal of the Building Policy of Herod?, in: D. M. Jacobson, N. Kokkinos (eds.), Herod and Augustus: Papers Presented at the IJS Conference, $21^{\text {st }}-23^{\text {rd }}$ June 2005, Leiden: 43-62.

Netzer, E. (1981a), Greater Herodium, Final Reports (Qedem 13), Jerusalem.

Netzer, E. (1981b), The Herodian Triclinia - A Prototype for the 'Galilean-Type' Synagogue, in: L. I. Levine (ed.), Ancient Synagogue Revealed, Jerusalem: 49-51.

Netzer, E. (1985), The Swimming Pools of the Hasmonaean Period at Jericho, Eretz-Israel 18: 344-352 (Hebrew).

Netzer, E. (1991), Masada III: The Buildings, Stratigraphy and Architecture, The Yigael Yadin Excavations 1963-1965, Final Reports, Jerusalem.

Netzer, E. (2001), The Hasmonean and Herodian Palaces at Jericho: Final Reports of the 1973-1987 Excavations, vol. I: Stratigraphy and Architecture, Jerusalem.

Netzer, E. (2006), The Architecture of Herod, the Great Builder, (Texts and Studies in Ancient Judaism 117), Tübingen.

Netzer, E. (2018), The Palaces of the Hasmoneans and Herod the Great, Reprinted and Expanded Edition, Jerusalem.

Netzer E., Damati, I. (2004), Cypros, in: E. Netzer, R. Laureys-Chachy (eds.), Hasmonean and Herodian Palaces at Jericho: Final Report of the 1973-1987 Excavations, vol. II: Stratigraphy and Architecture, Jerusalem: 233-280. 
Netzer, E., Kalman, Y., Porath, R., Chachy-Laureys, R. (2010), Preliminary Report on Herod's Mausoleum and Theatre with a Royal Box at Herodium, Journal of Roman Archaeology 23: 84-108.

Netzer, E., Porat, R., Kalman, Y., Chachy, R. (2013), Herodium, in: S. Rozenberg, D. Mevorah (eds.), Herod the Great, The King's Final Journey, Jerusalem: 126-161.

Oren, D. E. (1968), The 'Herodian Doves' in Light of Recent Archaeological Discoveries, Palestine Exploration Quarterly 100: 56-61.

Ovadiah, A. (2013), A Fragmentary Wall Painting in Herod's Theatre at Herodion: The Drinking Contest between Dionysus and Herakles, Revue Biblique 63: 351-359.

Ovadiah, A., Turnheim, Y. (2013), A Wall Painting in Herod's Theatre at Herodion: An Image of Elysium?, Revue Biblique 63: 343-349.

Palistrant Shaick, R. (2017), A Lion in Jerusalem: A Roman Sculpture of a Lion Head from the Jewish Quarter, in: H. Geva (ed.), Jewish Quarter Excavations in the Old City of Jerusalem, Conducted by Nahman Avigad 1969-1982, vol. VII: Areas $Q$ and H, Final Report, Jerusalem: 96-107.

Paltiel, E. (1991), Vassals and Rebels in the Roman Empire: Julio-Claudian Policies in Judaea and the Kingdoms of the East, Bruxelles.

Parrot, A. (1957), The Temple of Jerusalem, London.

Patrich, J., Weksler-Bdolah, S. (2016), The "Free Masons Hall": A Composite Herodian Triclinium and Fountain to the West of the Temple Mount, in: G. D. Stiebel et al. (eds.), New Studies in the Archaeology of Jerusalem and Its Region 10: 15*-38*.

Peleg, O., Rozenberg, S. (2008), Stuccowork in the Herodian Palaces, in: S. Rozenberg (ed.), Hasmonean and Herodian Palaces at Jericho - Final Reports of the 1973-1987 Excavations, vol. IV: The Decoration of Herod's Third Palace at Jericho, Jerusalem: 475-522.

Peleg-Barkat, O. (2007), The Herodian Architectural Decoration, in Light of the Finds from the Temple Mount Excavation, Ph.D. diss., Hebrew University of Jerusalem (Hebrew).

Peleg-Barkat, O. (2014), Fit for a King: Architectural Décor in Judaea and Herod as Trendsetter, Bulletin of the American Schools of Oriental Research 371: 141-161.

Peleg-Barkat, O. (2015), Tradition vs. Innovation: The Architectural Decoration of the Hasmonaean and Herodian Palaces in the Jericho Valley, Eretz-Israel 31: 325-341 (Hebrew).

Peleg-Barkat, O. (2017), The Temple Mount Excavations in Jerusalem, 1968-1978 Directed by Benjamin Mazar, Final Reports, vol. V: Herodian Architectural Decoration and King Herod's Royal Portico (Qedem 57), Jerusalem.

Peleg-Barkat, O., Ben Haim, A. (2017), Monumental Ionic Columns from Areas Q and H, in: H. Geva (ed.), Jewish Quarter Excavations in the Old City of Jerusalem, Conducted by Nahman Avigad 1969-1982, vol. VII: Areas $Q$ and H, Final Report, Jerusalem: 68-95.

Peleg-Barkat, O., Geva, H. (2017), Addendum 2: A Monumental Herodian Ionic Capital from the Royal Stoa? - A Reply to Ronny Reich, Israel Museum Studies in Archaeology 8: 91-95.

Peleg-Barkat, O., Geva, H., Reich, R. (2017), A Monumental Herodian Ionic Capital from the Upper City of Jerusalem, Israel Museum Studies in Archaeology 8: 74-88.

Re'em, A. (2018), The Qishle Excavation in the Old City of Jerusalem, Jerusalem.

Re'em, A. (2019), First and Second Temple Period Fortifications and Herod's Palace in the Jerusalem Kishle Compound, in: H. Geva (ed.), Ancient Jerusalem Revealed: Archaeological Discoveries, 1998-2018, Jerusalem: 136-144.

Richardson, P., Fisher, A. M. (2018), Herod: King of the Jews and Friend of the Romans, $2^{\text {nd }}$ ed., Abingdon.

Regev, E. (2010), Herod's Jewish Ideology Facing Romanization: On Intermarriage, Ritual Baths, and Speeches, Jewish Quarterly Review 100/2: 197-222.

Reich, R. (2013), Jewish Ritual Baths in the Second Temple, Mishnaic, and Talmudic Periods, Jerusalem (Hebrew).

Reich, R. (2017), Addendum 1: Where Was the Capital Incorporated?, Israel Museum Studies in Archaeology 8: 74-88.

Roller, D. W. (1998), The Building Program of Herod the Great, Berkeley. 
Roller, D. W. (2003), The World of Juba II and Kleopatra Selene: Royal Scholarship on Rome's African Frontier, New York-London.

Rozenberg, S. (2008), Hasmonean and Herodian Palaces at Jericho: Final Reports of the 1973-1987 Excavations IV: The Decoration of Herod's Third Palace at Jericho, Jerusalem.

Rozenberg, S. (2013), Interior Decoration in Herod's Palaces, in: S. Rozenberg, D. Mevorah (eds.), Herod the Great, The King's Final Journey, Jerusalem: 166-223.

Rozenberg, S. (2014), Figurative Paintings in Herodium: New Discoveries, in: N. Zimmerman (ed.), Antike Malerei zwischen Lokalstil und Zeitstil, Akten des XI. Internationalen Kolloquiums der AIPMA, 13.-17. September 2010 in Ephesos, Wien: 371-376.

Rozenberg, S. (2017), Between Alexandria and Rome, in: S. T. A. M. Mols, E. M. Moormann (eds.), Context and Meaning: Proceedings of the Twelfth International Conference of the Association Internationale pour la Peinture Murale Antique, Athens, September 16-20, 2013, (Babesch Supplement 31), Leuven: 229-235.

Schwartz, D. R. (2013), Herod the Great: A Matter of Perspective, in: S. Rozenberg, D. Mevorah (eds.), Herod the Great: The King's Final Journey, Jerusalem: 34-43.

Simons, J. (1952), Jerusalem in the Old Testament, Researches and Theories, Leiden.

Sivan, R., Solar, G. (1994), Excavations in the Jerusalem Citadel, 1980-1988, in: H. Geva (ed.), Ancient Jerusalem Revealed, Jerusalem: 168-176.

Snyder, F., Avraham A. (2013), The Opus Sectile Floor in a Caldarium of the Palatial Fortress at Cypros, in: R. Bar-Nathan, Y. Gärtner (eds.), Hasmonean and Herodian Palaces at Jericho - Final Reports of the 1973-1987 Excavations, vol. V: The Finds from Jericho and Cypros, Jerusalem: 178-202.

Stiebel, G. D. (2015), "Aqua regis" - Fountains of King Herod the Great, Eretz-Israel 31: 426-444.

Sullivan, R. (1990), Near Eastern Royalty and Rome, 100-30 BC, Toronto.

Tsafrir, Y. (2011), The Landscapes Reveals: Designing the Model of Jerusalem at the Holy Land Hotel, Hans Zvi Kroch, Michael Avi-Yonah, and an Unpublished Guidebook, Cathedra 140: 47-86.

Tsafrir, Y. (2015), A Response of a Society under Siege - Further Notes on the Jewish Attitude to Figural Art in the Second Temple Period and Following the Temple's Destruction, Eretz-Israel 31: 352-358 (Hebrew).

Tushingham, A. D. (1985), Excavations in Jerusalem 1961-1967, vol. I, Toronto.

Vermes, G. (2014), The True Herod, London.

Vörös, G. (2013), Machaerus I: History, Archeology and Architecture of the Fortified Herodian Royal Palace and $n$ City Overlooking the Dead Sea in Transjordan: Final Report of the Excavations and Surveys 1807-2012, Milan.

Vörös, G. (2015), Machaerus II: The Hungarian Archaeological Mission in the Light of the AmericanBaptist and Italian-Franciscan Excavations and Surveys: Final Report 1968-2015, Milan.

Vörös, G. (2019), Machaerus III: Final Report on the Herodian Citadel 1968-2018, Milan.

Wightman, G. J. (1990-1991), Temple Fortresses in Jerusalem, part II: The Hasmonean Baris and Herodian Antonia, Bulletin of the Anglo-Israel Archaeological Society 10: 7-35. 